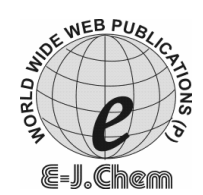

http://www.e-journals.net
ISSN: 0973-4945; CODEN ECJHAO

E-Journal of Chemistry 2008, 5(S1), 1063-1068

\title{
Synthesis of Bioactive Fluorinated 10H-Phenothiazines and their Sulfone Derivatives
}

\author{
YOGESH DIXIT $^{\S *}$, RAHUL DIXIT $^{\S}$, \\ NAVEEN GAUTAM and D.C. GAUTAM ${ }^{\S}$ \\ ${ }^{\S}$ Department of Chemistry, \\ University of Rajasthan, Jaipur-302004, India. \\ L.B.S. Govt. P.G. College, Kotputli, Jaipur-303108, India. \\ yogeshdixit15@yahoo.co.in
}

Received 2 June 2008; Accepted 1August 2008

\begin{abstract}
The present communication deals with the synthesis of a series of fluorinated $10 \mathrm{H}$-phenothiazines. $10 \mathrm{H}$-phenothiazines is prepared by Smiles rearrangement of substituted 2-foramido-2'-nitrodiphenylsulfide. Substituted 2-foramido-2'-nitrodiphenylsulfide were obtained by the reaction of 2-amino-3fluorobenzenethiol with $o$-halonitrobenzenes followed by formylation and 1-nitro/1-halo- $10 H$-phenothiazines have been prepared by the reaction of substituted 2-aminobenzenethiols with reactive $o$-halonitrobenzene containing a nitro group or halogen atom at $o$-position to the reactive halogen atom directly yielded 1-nitro/1-halo-10H-phenothiazines in situ. $10 \mathrm{H}$-phenothiazine sulfone derivatives have been synthesized by the oxidation of $10 \mathrm{H}$-phenothiazines by $30 \%$ hydrogen peroxide in glacial acetic acid. The structure of the synthesized compounds has been characterized by spectroscopic data and elemental analysis. Antimicrobial studies of the synthesized compounds have also been included.
\end{abstract}

Keywords: Antimicrobial activity, Phenothiazines, Smiles rearrangement, Sulfones.

\section{Introduction}

Phenothiazines (heterocyclic ring system consisting of two benzene rings ortho-fused to 1,4thiazine ring) and their analogues constituent an important class of bioactive heterocycles. They possess a wide spectrum of pharmacological/biological activities ${ }^{1-13}$ and their several derivatives are in clinical use. Phenothiazines have been found to possess promising medicinal activities used as tranquilizers, antihistamines, diuretics, analgesics, neurolepitcs, 
sedatives, antipsychotics, antiinflammatories, anthelmintics, antiemetics, antivirals, aneshetic, tuberculostatic, CNS depressants, anticancer, antidepressants, antipyretics, antiparkinson drugs, antibacterial and antifungal etc.

A slight change in the substitution pattern of phenothiazine nucleus causes a marked difference in their biological activities. So it has been considered worthwhile to extend our efforts to synthesize phenothiazines and their sulfone derivatives to make them available for biological screening in order to study the effects of structural change with the biological activities and to obtain the drugs of improved therapeutic effects and with minimum undesirable side effects. Kerby Bauer procedure ${ }^{14,15}$ have been used for antimicrobial activity of newly synthesized $10 H$-phenothiazines and sulfone derivatives.

\section{Experimental}

All the melting points were determined in open capillary tubes and are uncorrected. IR spectra were recorded in $\mathrm{KBr}$ on NICOLET-MEGNA FT-IR 550 spectrometer and the ${ }^{1} \mathrm{H}$ NMR spectra were recorded on JEOL AL-300 spectrometer (300 MHz) in $\mathrm{CDCl}_{3} / \mathrm{DMSO}^{-\mathrm{d}_{6}}$ using TMS, as an internal standard (chemical shifts are measured in $\delta \mathrm{ppm}$ ). Mass spectra were recorded on JEOL SX 102/DA 6000 using Argon/Xenonas FAB gas. The purity of the synthesized compounds were checked by TLC using silica gel "G" as adsorbent, visualizating these by UV light or Iodine chamber.

\section{Synthesis of 2-amino-2'-nitrodiphenylsulfides (III $\left.{ }_{a-b}\right)$}

To the refluxing solution of 2-amino-3-fluorobenzenethiol I ( 0.01 mole in $20 \mathrm{~mL}$ ethanol) and anhydrous sodium acetate $(0.01$ mole in $5 \mathrm{~mL}$ ethanol) was added in alcoholic solution of halonitrobenzene $\mathrm{II}_{\mathrm{a}, \mathrm{b}}(0.01$ mole in $20 \mathrm{~mL}$ of ethanol), refluxing was continued for four hours. The resultant solution was concentrated, cooled and kept overnight in an ice bath. The solid separated out was filtered, washed with $30 \%$ ethanol and recrystallized from methanol.

\section{Synthesis of 2-formamido-2'-nitrodiphenylsulfides $\left(I V_{a-b}\right)$}

The diphenylsulphides III $_{\mathrm{a}-\mathrm{b}}(0.01$ mole) obtained was refluxed for $4 \mathrm{~h}$ in $90 \%$ formic acid $(20 \mathrm{~mL})$. The contents were then poured into a beaker containing crushed ice, a solid separated out was filtered, washed with water until the filtrate was neutralized and crystallized from benzene.

\section{Synthesis of $10 H$-phenothiazines $\left(V_{a-b}\right)$}

To a refluxing solution of formyl derivatives $\operatorname{IV}_{\mathrm{a}-\mathrm{b}}(0.01 \mathrm{~mole})$ in acetone $(15 \mathrm{~mL})$ was added an alcoholic solution of potassium hydroxide $(0.2 \mathrm{gm}$ in $5 \mathrm{~mL}$ ethanol) was added. The contents were heated for 30 minutes. A second lot of potassium hydroxide $(0.2 \mathrm{gm}$ in $5 \mathrm{~mL}$ ethanol) was added to the reaction mixture and refluxed for $4 \mathrm{~h}$. The contents were poured into beaker containing crushed ice and filtered. The residue obtained was repeatedly washed with cold water and finally with $30 \%$ ethanol and then crystallized from benzene.

\section{Synthesis of phenothiazines $\left(V_{c-e}\right)$ by one step process}

A mixture of reactive o-halonitrobenzene $\mathrm{II}_{\mathrm{c}-\mathrm{e}}(0.01$ mole), 2-amino-3-fluoro/2-amino-3isopropyl and 2-amino-5-isopropylbenzenethiols I (0.01 mole), sodium hydroxide $(0.01$ mole $)$ and absolute alcohol $(25 \mathrm{~mL})$ was refluxed for two hours. The reaction mixture was concentrated on water bath, cooled and filtered. The precipitate was washed with hot water and ethanol and crystallized from acetone. 


\section{Synthesis of 10H-phenothiazine sulfones (VIa-e)}

To a solution of substituted $10 H$-phenothiazines $\mathrm{V}_{\mathrm{a} \text {-e }}(0.01$ mole $)$ in $20 \mathrm{~mL}$ of glacial acetic acid, $5 \mathrm{~mL}$ of $30 \%$ hydrogen peroxide was added and refluxed for fifteen minute. Heating was stopped and another lot of hydrogen peroxide $(5 \mathrm{~mL})$ was added. The reaction mixture was again refluxed for $3-4 \mathrm{~h}$. The contents were poured in a beaker containing crushed ice. The yellowish residue obtained was filtered and washed with water and recrystallized with ethanol.

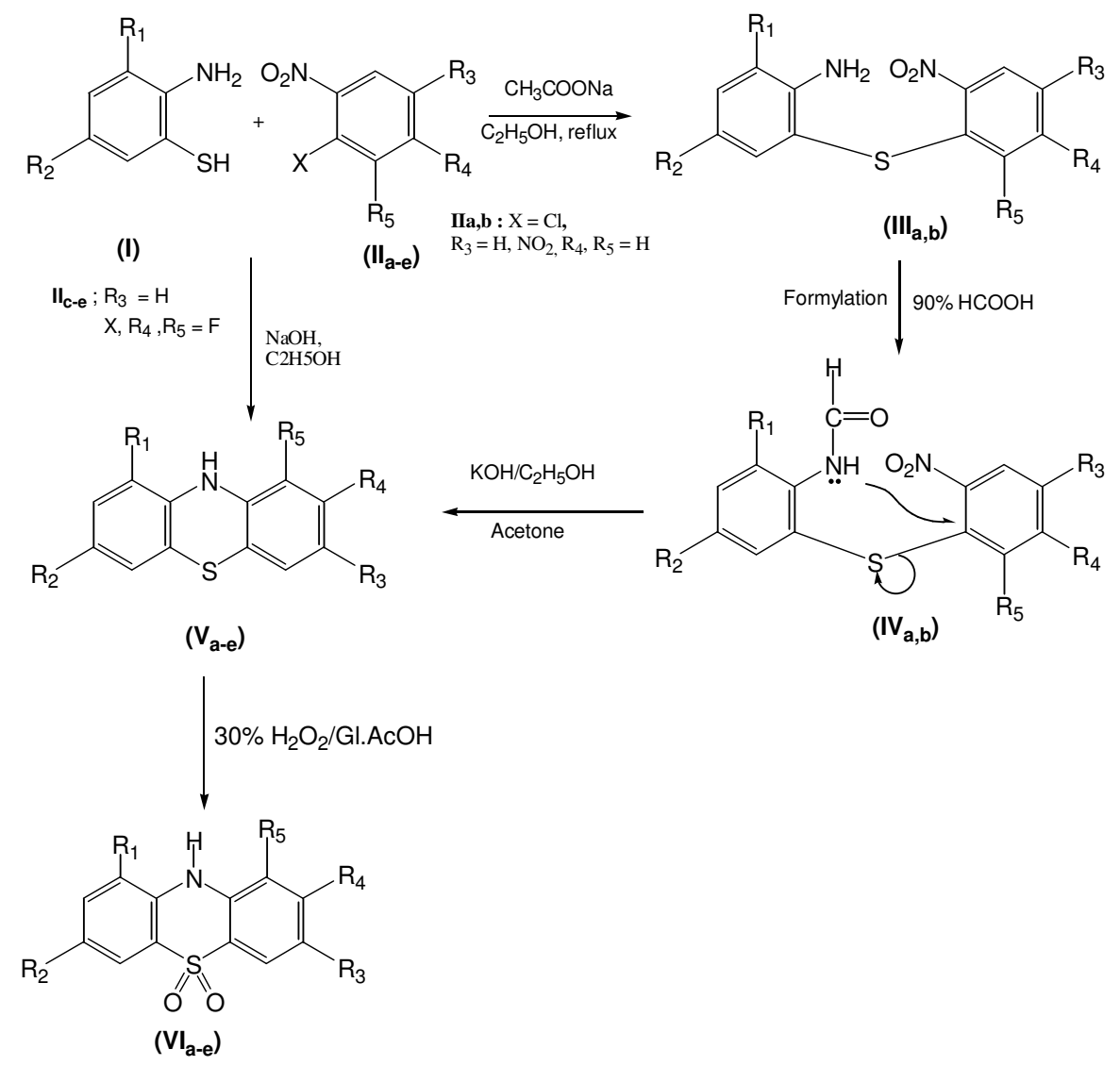

Scheme 1. Synthesis of $10 H$ - Phenothiazines and their sulfones

\section{Antimicrobial activity}

Newly synthesized compounds were screened for their antibacterial activity against Staphyllococcus aureus and Pseudomonas flueroscence bacterial strain by Kerby Bauer procedure using Streptomycin as standard drugs. Compounds are also screened for their antifungal activity against Aspergillus flavus and Aspergillus niger. The activity of each compound was compared with that of flukanozole as a standard drug. The results of such studies are given in Table 2. Antimicrobial activities are given in term of activity index. 
Table 1. Characterization data of phenothiazines and sulfones.

\begin{tabular}{|c|c|c|c|c|c|c|c|c|c|c|c|c|}
\hline \multirow{2}{*}{$\begin{array}{l}\text { Comd } \\
\text { No. }\end{array}$} & \multicolumn{5}{|c|}{ Compound } & \multirow{2}{*}{$\begin{array}{c}\text { Mol } \\
\text { wt }\end{array}$} & \multirow{2}{*}{ Yield \% } & \multirow{2}{*}{$\begin{array}{l}\text { m.p. } \\
{ }^{\circ} \mathrm{C}\end{array}$} & \multirow{2}{*}{$\begin{array}{c}\text { Molecular } \\
\text { formula }\end{array}$} & \multicolumn{3}{|c|}{$\%$ found (calcd.) } \\
\hline & $\mathrm{R}_{1}$ & $\mathrm{R}_{2}$ & $\mathrm{R}_{3}$ & $\mathrm{R}_{4}$ & $\mathrm{R}_{5}$ & & & & & $\mathrm{C}$ & $\mathrm{H}$ & $\mathrm{N}$ \\
\hline $\mathrm{V}_{\mathrm{a}}$ & $\mathrm{F}$ & $\mathrm{H}$ & $\mathrm{H}$ & $\mathrm{H}$ & $\mathrm{H}$ & 217 & 65 & 126 & $\mathrm{C}_{12} \mathrm{H}_{8} \mathrm{NSF}$ & $66.16(66.35)$ & $3.65(3.68)$ & $6.42(6.45)$ \\
\hline $\mathrm{V}_{\mathrm{b}}$ & $\mathrm{F}$ & $\mathrm{H}$ & $\mathrm{NO}_{2}$ & $\mathrm{H}$ & $\mathrm{H}$ & 262 & 69 & 93 & $\mathrm{C}_{12} \mathrm{H}_{7} \mathrm{~N}_{2} \mathrm{O}_{2} \mathrm{SF}$ & $54.79(54.96)$ & $2.67(2.67)$ & $10.65(10.68)$ \\
\hline $\mathrm{V}_{\mathrm{c}}$ & $\mathrm{F}$ & $\mathrm{H}$ & $\mathrm{H}$ & $\mathrm{F}$ & $\mathrm{F}$ & 253 & 69 & 280 & $\mathrm{C}_{12} \mathrm{H}_{6} \mathrm{NSF}_{3}$ & $56.74(56.91)$ & $2.37(2.37)$ & $5.50(5.53)$ \\
\hline $\mathrm{V}_{\mathrm{d}}$ & $\mathrm{H}$ & $\left(\mathrm{CH}_{3}\right)_{2} \mathrm{CH}$ & $\mathrm{H}$ & $\mathrm{F}$ & $\mathrm{F}$ & 277 & 74 & 240 & $\mathrm{C}_{15} \mathrm{H}_{13} \mathrm{NSF}_{2}$ & $64.72(64.98)$ & 4.67(4.69) & $5.03(5.05)$ \\
\hline $\mathrm{V}_{\mathrm{e}}$ & $\left(\mathrm{CH}_{3}\right)_{2} \mathrm{CH}$ & $\mathrm{H}$ & $\mathrm{H}$ & $\mathrm{F}$ & $\mathrm{F}$ & 277 & 65 & 245 & $\mathrm{C}_{15} \mathrm{H}_{13} \mathrm{NSF}_{2}$ & $64.74(64.98)$ & $4.66(4.69)$ & $5.04(5.05)$ \\
\hline $\mathrm{VI}_{\underline{\mathrm{a}}}$ & F & $\mathrm{H}$ & $\mathrm{H}$ & $\mathrm{H}$ & $\mathrm{H}$ & 249 & 67 & 170 & $\mathrm{C}_{12} \mathrm{H}_{8} \mathrm{NSO}_{2} \mathrm{~F}$ & $57.70(57.83)$ & $2.70(2.72)$ & $9.49(9.52)$ \\
\hline $\mathrm{VI}_{\mathrm{b}}$ & $\mathrm{F}$ & $\mathrm{H}$ & $\mathrm{NO}_{2}$ & $\mathrm{H}$ & $\mathrm{H}$ & 294 & 55 & 140 & $\mathrm{C}_{12} \mathrm{H}_{7} \mathrm{~N}_{2} \mathrm{O}_{4} \mathrm{SF}$ & $48.85(48.97)$ & $2.36(2.38)$ & $9.50(9.52)$ \\
\hline $\mathrm{VI}_{\mathrm{c}}$ & $\mathrm{F}$ & $\mathrm{H}$ & $\mathrm{H}$ & $\mathrm{F}$ & $\mathrm{F}$ & 285 & 68 & 184 & $\mathrm{C}_{12} \mathrm{H}_{6} \mathrm{NSO}_{2} \mathrm{~F}_{3}$ & $50.35(50.52)$ & $2.09(2.10)$ & $4.89(4.91)$ \\
\hline $\mathrm{VI}_{\mathrm{d}}$ & $\mathrm{H}$ & $\left(\mathrm{CH}_{3}\right)_{2} \mathrm{CH}$ & $\mathrm{H}$ & $\mathrm{F}$ & $\mathrm{F}$ & 309 & 54 & 210 & $\mathrm{C}_{15} \mathrm{H}_{13} \mathrm{NSO}_{2} \mathrm{~F}_{2}$ & $58.09(58.25)$ & $4.17(4.20)$ & $4.51(4.53)$ \\
\hline $\mathrm{VI}_{\mathrm{e}}$ & $\left(\mathrm{CH}_{3}\right)_{2} \mathrm{CH}$ & $\mathrm{H}$ & $\mathrm{H}$ & $\mathrm{F}$ & $\mathrm{F}$ & 309 & 61 & 199 & $\mathrm{C}_{15} \mathrm{H}_{13} \mathrm{NSO}_{2} \mathrm{~F}_{2}$ & $58.06(58.25)$ & $4.18(4.20)$ & $4.50(4.53)$ \\
\hline
\end{tabular}

Table 2. $\mathrm{R}$ and ${ }^{1} \mathrm{H}$ NMR spectral data and antimicrobial activity of synthesized compounds.

\begin{tabular}{|c|c|c|c|c|c|c|c|c|c|}
\hline \multirow{2}{*}{$\begin{array}{l}\text { Compound } \\
\text { No. }\end{array}$} & \multicolumn{3}{|c|}{$\mathrm{IR}\left(\mathrm{KBr}: v_{\max } \mathrm{cm}^{-1}\right)$} & \multicolumn{2}{|c|}{$\begin{array}{c}{ }^{1} \mathrm{H} \text { NMR }(\delta \text { ppm from } \\
\text { TMS }\end{array}$} & \multicolumn{2}{|c|}{ Antibacterial activity } & \multicolumn{2}{|c|}{ Antifungal activity } \\
\hline & $>\mathrm{NH}$ & $\stackrel{O}{N} \rightarrow 0$ & $\mathrm{C}-\mathrm{F}$ & $\begin{array}{c}>\mathrm{NH} \\
\text { Singlet }\end{array}$ & $\begin{array}{c}\text { Ar-H } \\
\text { Multiplet }\end{array}$ & S. aurivs & P. flueroscence & A. niger & A. flavus \\
\hline $\mathrm{V}_{\mathrm{a}}$ & 3380 & - & 1260 & 9.31 & $7.52-6.80$ & 0.94 & 0.89 & 0.99 & 0.91 \\
\hline $\mathrm{V}_{\mathrm{b}}$ & 3410 & 15851380 & 1270 & 9.18 & $8.15-7.15$ & 0.95 & 1.00 & 0.87 & 0.82 \\
\hline $\mathrm{V}_{\mathrm{c}}$ & 3220 & - & 1295 & 9.22 & $7.70-6.35$ & 0.81 & 0.78 & 0.98 & 0.94 \\
\hline $\mathrm{V}_{\mathrm{d}}$ & 3280 & - & 1290 & 9.65 & $8.10-6.72$ & 0.94 & 0.96 & 0.81 & 0.76 \\
\hline $\mathrm{V}_{\mathrm{e}}$ & 3290 & - & 1285 & 9.70 & $8.30-6.70$ & 0.96 & 0.98 & 0.80 & 0.74 \\
\hline $\mathrm{VI}_{\mathrm{a}}$ & 3380 & - & 1260 & 9.30 & $7.62-6.82$ & 0.94 & 0.90 & 0.91 & 0.85 \\
\hline $\mathrm{VI}_{\mathrm{b}}$ & 3405 & 15801385 & 1295 & 9.21 & $8.20-7.22$ & 0.96 & 0.98 & 0.86 & 0.85 \\
\hline VIc & 3215 & - & 1270 & 9.23 & $7.72-6.32$ & 0.84 & 0.80 & 0.94 & 0.96 \\
\hline $\mathrm{VI}_{\mathrm{d}}$ & 3275 & - & 1275 & 9.71 & $8.10-6.80$ & 0.92 & 0.83 & 0.73 & 0.74 \\
\hline VIe & 3290 & - & 1275 & 9.72 & $8.40-6.80$ & 0.93 & 0.95 & 0.78 & 0.71 \\
\hline
\end{tabular}

Antimicrobial activities are given in term of activity index

Activity index $=\underline{\text { Inhibition diameter of test compound }}$

Inhibition diameter of standard 


\section{Results and Discussion}

2-Amino-3-fluorobenzenethiol I was condensed with $o$-halonitrobenzenes $\mathrm{II}_{\mathrm{a}, \mathrm{b}}$ (2chloronitrobenzene and 2,4-dinitrochlorobenzene) to gave substituted 2-amino-2'nitrodiphenyl sulfides $\mathrm{III}_{\mathrm{a}, \mathrm{b}}$, which on formylation with $90 \%$ formic acid and substituent treatment with alcholic $\mathrm{KOH}$ underwent smiles rearrangement yielding fluorinated $10 H$-phenothiazines. When reactive o-halonitrobenzene (containing a nitro group as well as halogen atom at ortho position to the reactive halogen atom) condensed with 2aminobenzenethiols, yielded $10 H$-phenothiazines in a single step. Here cyclisation take place with the preference of halogen elimination and Smiles rearrangement as well as ring closure occurs simultaneously and in situ. Fluorinated $10 \mathrm{H}$-phenothiazines $5_{\mathrm{c} \text {-e }}$ have been prepared by condensation of 2-amino-3-fluoro/2-amino-3-isopropyl and 2-amino-5isopropylbenzenethiols with reactive halonitrobenzene $\mathrm{II}_{\text {c-e }}$.

Substituted $10 \mathrm{H}$-phenothiazine $\left(\mathrm{V}_{\mathrm{a}-\mathrm{e}}\right)$ converted into corresponding sulfones $\left(\mathrm{VI}_{\mathrm{a}-\mathrm{e}}\right)$ by oxidation with $30 \%$ hydrogenperoxide in glacial acetic acid (Scheme 1). The structures of all the synthesized compounds are characterized by spectroscopic data and elemental analysis. Kerby-Bauer procedure (Filter paper disc method) has been used for study of antimicrobial activity of newly synthesized compound.

The structure assignment of these compounds was made on basis of elemental analysis (Table 1) and spectral data (Table 2). The characteristic IR bands and ${ }^{1} \mathrm{H}$ NMR data of compounds $\left(\mathrm{V}_{\mathrm{a}-\mathrm{e}}\right)$ and $\left(\mathrm{VI}_{\mathrm{a}-\mathrm{e}}\right)$ are presented in Table 2 .

\section{IR spectra}

Compounds $\left(\mathrm{V}_{\mathrm{a}-\mathrm{e}}\right)$ and $\left(\mathrm{VI}_{\mathrm{a}-\mathrm{e}}\right)$ exhibit a single sharp peak in the region $3410-3275 \mathrm{~cm}^{-1}$ due to N-H stretching vibration. Compound $\mathrm{V}_{\mathrm{b}}$ and $\mathrm{VI}_{\mathrm{b}}$ exhibit peaks $1585-1580 \mathrm{~cm}^{-1}$ and $1385-1380 \mathrm{~cm}^{-1}$ due to assymetric and symmetric stretching vibrations of $-\mathrm{NO}_{2}$ group. Compounds $\left(\mathrm{V}_{\mathrm{a}-\mathrm{e}}\right)$ and $\left(\mathrm{VI}_{\mathrm{a}-\mathrm{e}}\right)$ also exhibit a single peak in the region $1295-1260 \mathrm{~cm}^{-1}$ due to $\mathrm{C}-\mathrm{F}$ stretching vibrations. Sulfones derivatives of these $10 \mathrm{H}-\mathrm{Phenothiazines} \mathrm{exhibit}$ three characteristic absorption peaks as symmetric stretching $v_{1}\left(1195-1140 \mathrm{~cm}^{-1}\right)$, Asymmetric stretching $v_{3}\left(1380-1370 \mathrm{~cm}^{-1}\right)$ and banding vibration $v_{2}\left(575-520 \mathrm{~cm}^{-1}\right)$ in chloroform solution.

\section{NMR Spectra}

All the synthesized compounds show a singlet in the region $\delta 9.72-9.18 \mathrm{ppm}$ is due to $\mathrm{N}-\mathrm{H}$ protons. Multiplet due to aromatic protons appeared in the region $\delta 8.40-6.32 \mathrm{ppm}$. (Table 2).

\section{Mass spectra}

In mass spectra molecular ion peak are in accordance with their molecular weight.

\section{Conclusion}

The structure proposed to the synthesized compound is well supported by spectroscopic data and elemental analysis. From the antimicrobial activity data (Table 2), it may be concluded that all the synthesized compounds showed good and moderate activity against the antimicrobes. 


\section{Acknowledgement}

Authors are thankful to the Department of Chemistry and the Department of Botany, University of Rajasthan, Jaipur for providing laboratory facilities. Authors are also thankful to Central Drug Research Institute, Lucknow for providing spectra. Thanks are due to UGC (Bhopal) for financial support.

\section{References}

1. Galbraith F and Smiles S, J Chem Soc., 1935, 1234.

2. Clercq E D, Nucleosids and Nucleotides, 1985, 4, 3.

3. Gupta R R Ed., Phenothiazines and 1,4-Benzothiazines - Chemicals and Biomedical Aspects, Elsevier, Amsterdom, 1988.

4. Pumima A, Mathur N, Gupta V and Ojha K G, Pharmazie, 1991, 46(12), 885.

5. Gupta A, Saraswat V, Mukhrji S K and Gupta R R, Phosphorus, Sulfur and Silicon, 1993, 85, 101.

6. Shukla S and Prakash L, Indian J Heterocycl Chem., 1995, 5, 41.

7. Studenik C, Gruber R L and Heistraacher P, Pharmazie, 54(5), 1999, 330-34; Chem. Abstr., 1999, 131, 195.

8. Gautam N, Gupta R, Gautam D C and Gupta R R, Heterocyclic Commun., 2000, 6, 369.

9. Kumar G, Gupta V, Gautam D C and Gupta R R, Heterocyclic Commun., 2002, 8, 381.

10. Gautam N and Gautam D C, Int J Chem Sci., 2004, 2(1), 84-87.

11. Gautam N, Hans D and Gautam D C, Oriental J Chem., 2005, 21(2), 299-302.

12. Gautam N and Gautam D C, Oriental J Chem., 2006, 22(2), 457-460.

13. Gautam V, Sharma M, Samarth A, Kumar A, Sharma I K, Gautam N and Gautam D C, Phosphorus, sulfur, silicon and related elements, 2007, 182(6), 1381.

14. Singh G, Kumar N, Yadav A K and Mishra A K, Heteroatom Chemistry, 2003, 14(6), 481-486.

15. Collin J C H and Lyne P M, Microbiol Methods University Park Press Baltimore, 1970. 


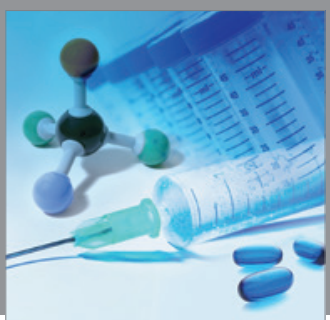

International Journal of

Medicinal Chemistry

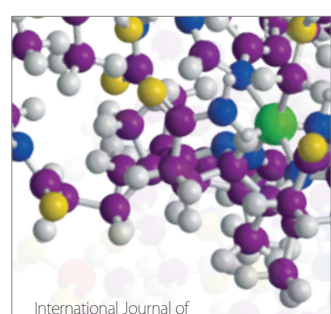

Carbohydrate Chemistry

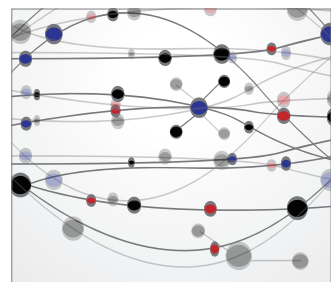

The Scientific World Journal
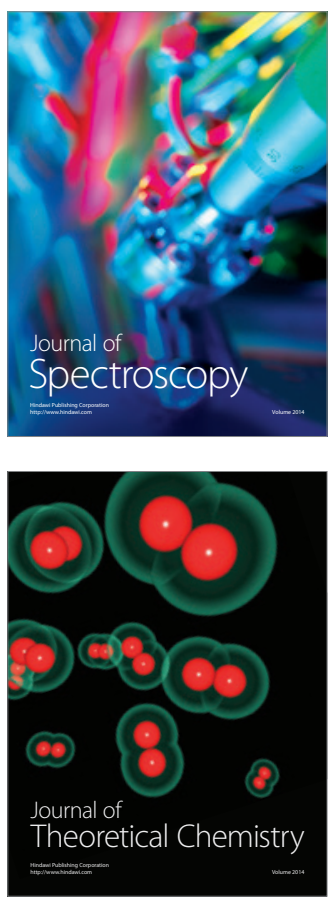
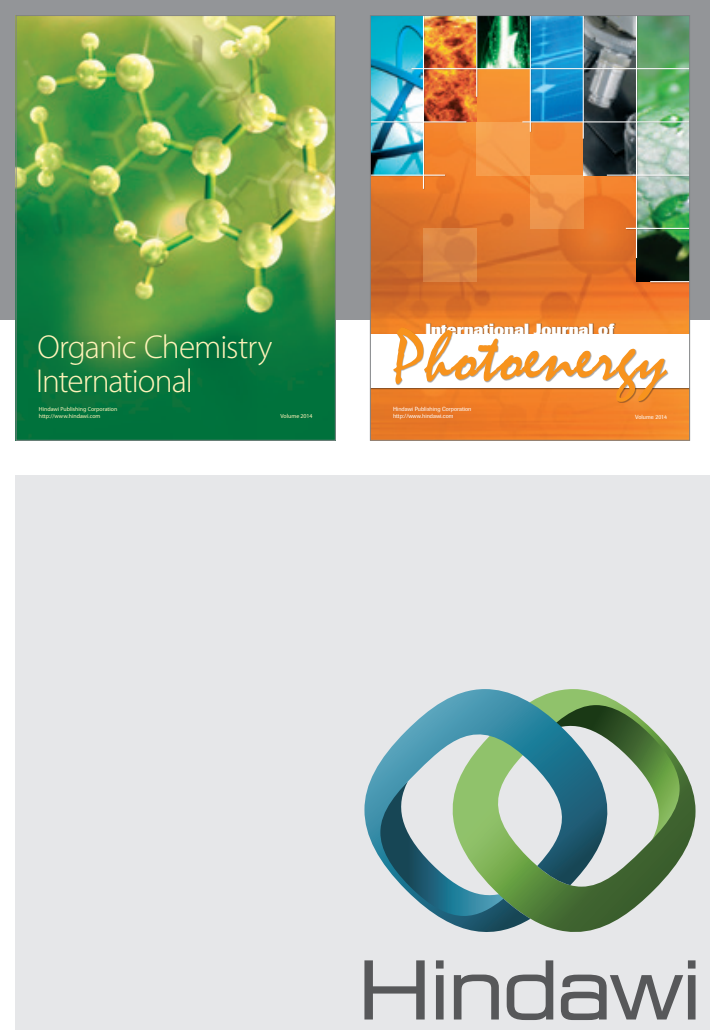

Submit your manuscripts at

http://www.hindawi.com
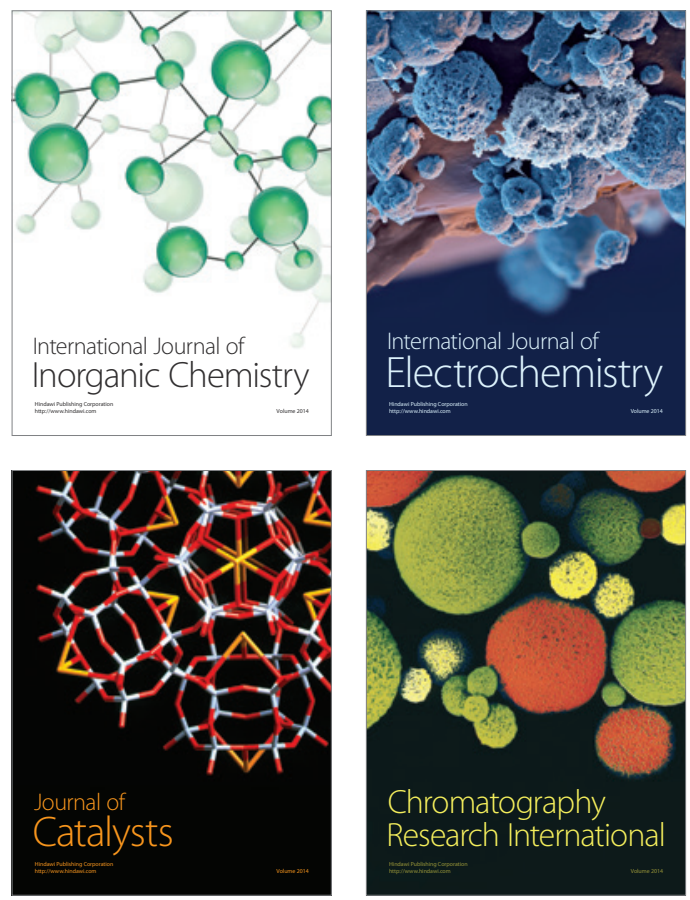
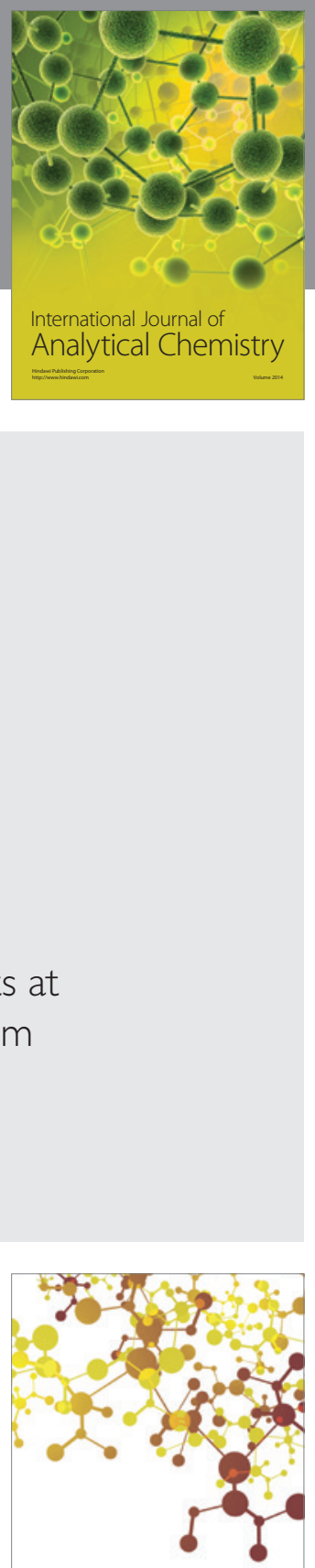

Journal of

Applied Chemistry
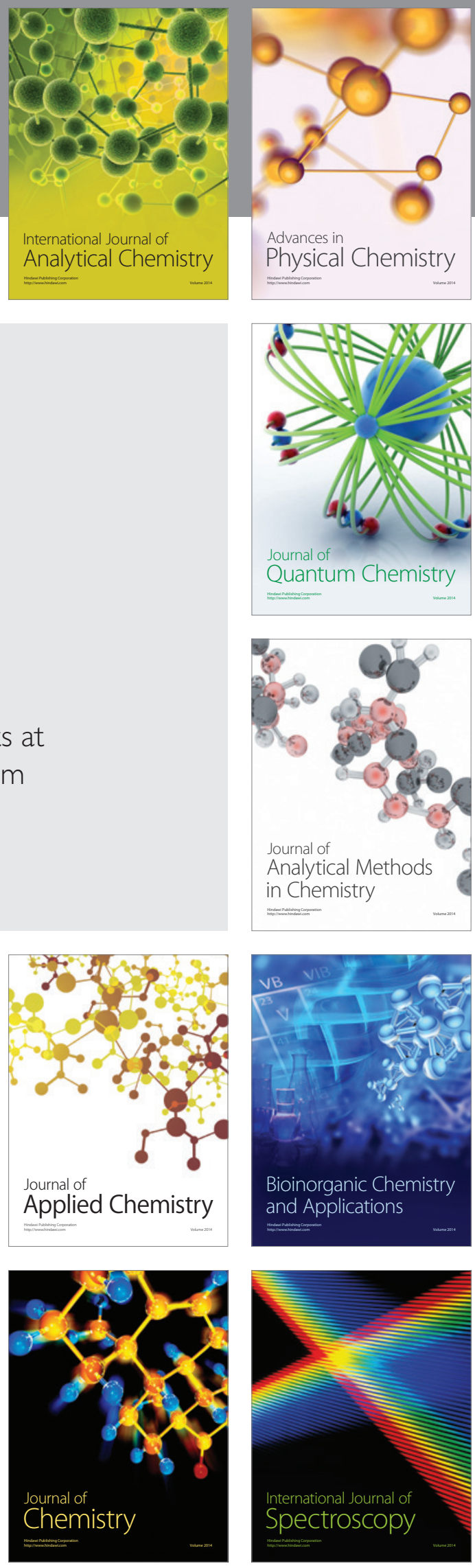